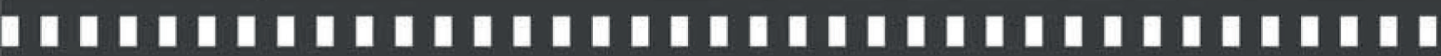

\author{
A recriação poética da palavra na fotografia \\ do filme "0 veneno da madrugada", de \\ Ruy Guerra
}

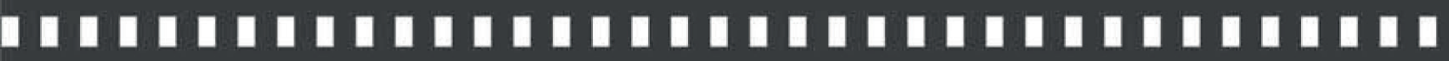

\author{
Ane Carolina Randig Tavares
}

Josette Monzani

Artigo recebido em: 27/04/2016

Artigo aprovado em: 02/12/2016 


\title{
A recriação poética da palavra na fotografia do filme " 0 veneno da madrugada", de Ruy Guerra
}

The poetic word recreation in the photography of the movie " 0 veneno da madrugada", by Ruy Guerra

\author{
Ane Carolina Randig Tavares* e Josette Monzani***
}

\begin{abstract}
Resumo: A proposta deste artigo é apresentar alguns aspectos referentes à fotografia de $O$ veneno da madrugada (2006), dirigido por Ruy Guerra, inspirado no romance La mala hora (1962) de Gabriel García Márquez. No filme em questão, a luz que tinge o quadro filmico ressalta a atmosfera emocional e simbólica presente no texto garcíamarqueziano. Nesse sentido, pretende-se mostrar um dos elementos do discurso cinematográfico, a fotografia, que foi traduzido a fim de recriar os sentidos de dualidade e ambiguidade que permeiam a narrativa do romance.
\end{abstract}

Palavras-chave: Literatura. Cinema. O veneno da madrugada. Tradução intersemiótica.

\begin{abstract}
The proposal of this paper to present some aspects referents to the phoyography of the movie O veneno da madrugada (2006), directed by Ruy Guerra and inspired on the Gabriel García Márquez's novel La mala hora (1962). In this movie, the light which dyes the filmic frame highlights the emotional and symbolic atmosphere existing in the Garcia Marquez novel. In this sense, we intend to show one of the elements of the cinematographic discourse, the photography, which was translated in order to recreate the meaning of duality and ambiguity that permeate the novel's narrative.
\end{abstract}

Keywords: Literature. Cinema. La mala hora. Intersemiotic translation.

* Possui graduação em Letras (Habilitação Português-Espanhol) pela Universidade Federal de Mato Grosso do Sul - UFMS, Campus Pantanal (2010) e mestrado em Estudos de Literatura pela Universidade Federal de São Carlos - UFSCar (2013).

** Possui graduação em Comunicação Visual, doutorado em Comunicação e Semiótica pela Pontifícia Universidade Católica de São Paulo e pós-doutorado em Cinema, pela ECA-USP. Atualmente é professora do Bacharelado e do Mestrado em Imagem e Som do Departamento de Artes e Comunicação da Universidade Federal de São Carlos. 


\section{Palavras iniciais}

O universo literário do escritor Gabriel García Márquez sempre despertou, e continua despertando, o interesse de roteiristas e diretores de diversos países. Inúmeras de suas narrativas foram recriadas e levadas às telas de televisão e cinema. A título de exemplo, seguem algumas destas produções: En este pueblo no hay ladrones (1964), adaptado pelo diretor mexicano Alberto Isaac; La viuda de Montiel (1979), dirigido pelo chileno Miguel Littin; Un señor muy viejo con unas alas enormes (1988) pelo diretor argentino Fernando Birri; Crónica de una muerte anunciada (1987), por Francesco Rosi, diretor italiano; El coronel no tiene quien le escriba (1998), pelo diretor mexicano Arturo Ripsten; El amor en los tiempos de cólera (2007) pelo diretor americano Mike Newell; Del amor y otros demonios (2009) pela diretora costariquense Hilda Hidalgo.

Nascido em Lourenço Marques (Moçambique, África) e vivendo no Brasil desde 1958, Ruy Guerra ${ }^{1}$ também pertence à seleta lista de cineastas que tem se 'atrevido' a levar às telas os romances do autor colombiano. O veneno da madrugada (2006), objeto de nossa leitura, é a quarta incursão do cineasta no universo imaginário de García Márquez. Trata-se de uma parceria que se realizou, com sucesso, em produções anteriores como Erendira (1983); A fábula da bela Palomera (1988); e Alugo-me para sonhar (1989).

Tendo em vista uma perspectiva que considera a relação entre literatura e cinema, a leitura aqui proposta busca analisar como acontece o diálogo intersemiótico entre o filme $\mathrm{O}$ veneno da madrugada, filme este inspirado em um dos primeiros romances de Gabriel García Márquez, La mala hora (1962). Para realizar

$1 \quad$ Ruy Guerra tem uma carreira consolidada no Brasil desde a época do Cinema Novo. De sua filmografia, destaca-se Os cafajestes (1962), seu primeiro longa metragem. Dirigiu também Os fuzis, de 1964, um dos clássicos da estética da fome (conceito de Glauber Rocha), rótulo que identificava grande parte dos filmes dos anos 1960 no Brasil. 
esta aproximação, foram basilares os conceitos de tradução intersemiótica de Roman Jakobson (1977) e de recriação de Haroldo de Campos (2004). Para os teóricos, o ato de tradução é entendido como um processo de recriação de formas e de expansão da significação: traduzir, nesse sentido, não é apenas repetir o sentido literal de uma obra "original", mas sim (re)inventar, (re) compor, (re)criar e ampliar as possibilidades de leitura estética em outra linguagem ${ }^{2}$.

No filme em questão, a luz que tinge o quadro fílmico é explorada com força pelo diretor de fotografia, Walter Carvalho. É nítida a atmosfera emocional e simbólica criada pela iluminação. Em vários momentos ela é fortemente focalizada dirigindo o olhar do receptor. Em outros, cria fortes contrastes (claro-escuro). Essas escolhas estéticas parecem chamar a atenção do espectador para os sentidos que remetem ao plano de significação profunda presente no romance.

Nesse sentido, pretende-se averiguar de que maneira o cineasta manipulou a fotografia fílmica, a fim de recriar os sentidos de dualidade e ambiguidade que permeiam a narrativa do romance. Foram selecionados alguns frames (quadros), e nesses, priorizouse a observação dos seguintes itens relacionados à estruturação da imagem: a disposição da iluminação, a escassez de luz, os altos contrastes, as sombras projetadas e os enquadramentos.

2 O teórico Roman Jakobson (1977, p. 64-65, 72) foi um dos pioneiros a tratar a questão da tradução intersemiótica. "A tradução intersemiótica ou transmutação consiste na interpretação dos signos verbais por meio de sistemas de signos não verbais, como, por exemplo, da arte verbal para a música, a dança, o cinema ou a pintura". Ao discutir aspectos linguísticos da tradução, Jakobson defende que "a poesia é, por definição, intraduzível, sendo possível apenas sua transposição criativa". É essa ideia que fundamenta as concepções de Haroldo de Campos sobre tradução. Para Campos, a tradução de textos criativos "será sempre recriação, ou criação paralela, autônoma, porém recíproca”. 


\section{O romance: dualidade (ser - parecer) em La mala hora}

La mala hora conta a história de um povoado no qual sua população é afetada pela aparição de bilhetes anônimos que relatam histórias desconfortantes para os seus moradores. A aparição dos pasquins serve para evidenciar a existência dos três poderes da cidade: o econômico, representado pela família Asís; o político, representado pelo alcaide; e o religioso, representado pelo padre Ángel. Os três poderes se 'unem' para combater os bilhetes anônimos, contudo fracassam na empreitada, o que aumenta a situação de tensão na cidade. À medida que se adentra no universo ficcional, tem-se a impressão que duas narrativas concorrem na mesma história. Há uma situação aparente, na qual tudo está dentro da normalidade, e uma situação anômala, na qual nem tudo o que parece ser, é, e personagens quase anônimos e secundários vão ganhando relevo e sentido.

A partir do conhecimento dessa situação básica narrada no romance, buscou-se aplicar os estudos desenvolvidos por Greimas (1966) em que o autor distingue dois níveis da gramática narrativa: o superficial e o profundo. O nível profundo compreende um sistema conceitual que se pode analisar com ajuda do quadrado semiótico $^{3}$, modelo da estrutura elementar de toda significação. Esse nível constitui a base e possui o modelo da estrutura elementar da significação do relato concreto, a estrutura superficial. Assim, pode-se averiguar que essa estrutura binária - de ser e parecer atua no romance para produzir um efeito não só de contradição, mas de dualidade, na qual o povoado vive as duas situações simultaneamente. Ao mesmo tempo em que os cidadãos que

3 Esta análise foi realizada em detalhes, em outra oportunidade, contudo não cabe no formato deste trabalho. Aqui, pretende-se apenas mencionar e deixar claro ao leitor que essa estrutura ser-parecer se faz presente em toda a narrativa do romance. Informação fundamental para prosseguir as análises que envolvem aspectos da tradução intersemiótica livro-filme. 
dominam a política e a economia da cidade aparentemente seguem a moral e os bons costumes (parecer) pregados pela igreja, burlam as regras impostas pelo pároco (ser) e pelas leis. Todo o povoado vive na dualidade de ser e parecer: enquanto vive uma aparente ordem e harmonia, vive afundado na sujeira política e econômicosocial, como a vaca morta que apodrece no brejo e a sujeira das pombas que exalam odores fétidos pelas casas e ruas.

Era el mecanismo del pueblo funcionando a precisión: primero, las cinco campanadas de las cinco; después, el primer toque para misa, y después, el clarinete de Pastor, en el patio de su casa, purificando con notas diáfanas y articuladas el aire cargado de porquería de palomas (GARCÍA MÁRQUEZ, 2010, p. 7).

Após esta sucinta explanação sobre o romance - na tentativa de evidenciar a estrutura de ser e parece que enlaça a história pretende-se, neste momento, explicitar alguns dos vínculos formais que aproximam essas obras, buscando compreender alguns dos recursos expressivos que foram empregados por Ruy Guerra ao traduzir em imagens a estrutura binária (ser/parecer) que perpassa toda a história do romance. Neste ponto, vale lembrar, com Richards (1971, p. 124) que "a comparação e a elaboração de analogias não envolvem um esforço em fazer uma arte legislar por outra ou obscurecer suas diferenças ou destruir sua autonomia". Trata-se, antes de tudo, de procurar estabelecer equivalências que, uma vez bem apreendidas, possam ampliar a compreensão de cada um dos sistemas de expressão.

\section{A luz que tinge o quadro fílmico}

Ao assistirmos ao filme reconhecemos o romance principalmente pela caracterização das personagens e a 
reconstituição do ambiente cenográfico, já que Guerra situa a história num pequeno vilarejo localizado de maneira rarefeita no tempo e no espaço tal como no livro. O olhar apurado irá ainda perceber no filme, sobretudo por meio do trabalho de iluminação, ressonâncias poéticas do relato de partida (o romance).

Ao abordar a intencionalidade da imagem, afirma-se o desejo de atingir e transmitir algo, ou seja, deixar fluir a mensagem ao receptor. E para que seja possível a recepção-reação, manipula-se a mensagem e a sua estrutura para tal efeito. Sem dúvida, o elemento visual explorado com força na diegese cinematográfica para tocar os diversos sentidos do texto-fonte, é a luz. Ao falar em percepção visual é importante esclarecer que a luz é o fator essencial para tal evento. Segundo Arnheim (2002) a importância da luz está além das explicações físicas, ela transborda e banha outros campos do conhecimento, inclusive, o psicológico e o simbólico.

Ao longo dos primeiros minutos do filme, deparamonos com uma fotografia soberbamente pouco iluminada que vai causando desconforto e estranhamento aos olhos. Tudo é muito obscuro e, nesse momento inicial, é difícil estabelecer associações. Com o desenrolar da trama e principalmente com a insistência desse elemento cênico (photo-escura) percebe-se que o signo ora apresentado trata-se não apenas de um elemento indicial de aspecto escuro e ambíguo que se refere à noite na qual começa o filme, mas um elemento icônico gerador da 'atmosfera' de chuva, lamaçal e abafamento que paira sobre o vilarejo durante quase toda a narrativa.

A tela como um espaço plástico é parecida com o espaço plástico da pintura. Percebemos, então que este espaço de representações se faz através de proporções e volumes. O mesmo se aplica ao cinema: a película, antes de ser impressa pela luz, não passa de várias camadas e de milhares de pigmentos. Ao serem atingidos pela luz, esses pigmentos tomarão, em relação uns aos outros, um cromatismo que se reverterá, na somatória, numa luz global (LEONE; MOURÃO, 1993, p. 37). 
O quadro foi pintado pela luz do fotógrafo Walter Carvalho que segue uma trajetória na qual seu material de trabalho, a luz, funciona como elemento dramático e narrativo. Ele já fotografou mais de 60 filmes $^{4}$, dos quais destacam-se: Central do Brasil (1998) de Walter Salles; Madame Satã (2001) de Karin Aïnuz; Lavoura Arcaica (2001) de Luiz Fernando Carvalho; Filme de Amor (2003) de Júlio Bressane. Nessas produções, o trabalho de Carvalho também se integra ao universo do realizador como dado expressivo.

A análise proposta acontecerá por meio de apontamentos em determinadas passagens do filme. Por esse motivo foram selecionados alguns frames ou quadros para que sejam neles mostrados e comentados itens relacionados à estruturação, como: a disposição da iluminação, o movimento causado por tal elemento visual, a escassez de luz, os contrastes e a sombra projetada.

\section{Musgo, ocre, penumbra, luz de vela, lampião!}

$\mathrm{O}$ veneno da madrugada se passa numa noite chuvosa e, na conversa, Ruy me dizia palavras como musgo, ocre, penumbra, luz de vela, luz de lampião: são as bases da fotografia do filme ${ }^{5}$. (LEAL, 2012)

Em $O$ veneno da madrugada predominam duas fotografias: uma escura (tendendo ao verde escuro e ao preto; ao podre e sem vida) e uma clara (amarelada, de vida, de esperança). Isso parece uma informação óbvia, mas, ao se olhar mais de perto e com cuidado percebe-se que esse jogo - claro-escuro - vai ganhando diferentes matizes em função da intencionalidade da mensagem a ser traduzida.

A partir da leitura dos quadros selecionados (Figura 1),

$4 \quad$ Direção e/ou direção de fotografia.

5 Entrevista com o diretor de fotografia Walter Carvalho, (LEAL, 2012). 
pode-se observar que tanto o dia como a noite, assim como os ambientes internos e externos, são banhados por uma luz amarela, embora ocorra diferenciação na quantidade e distribuição desta luz em cada cenário. A vibração cromática contrastante entre claro e escuro que oscila da imagem é o primeiro elemento que remete às ideias de dualidade, melancolia e soturnidade.

Figura 1 - ambientações interna e externa
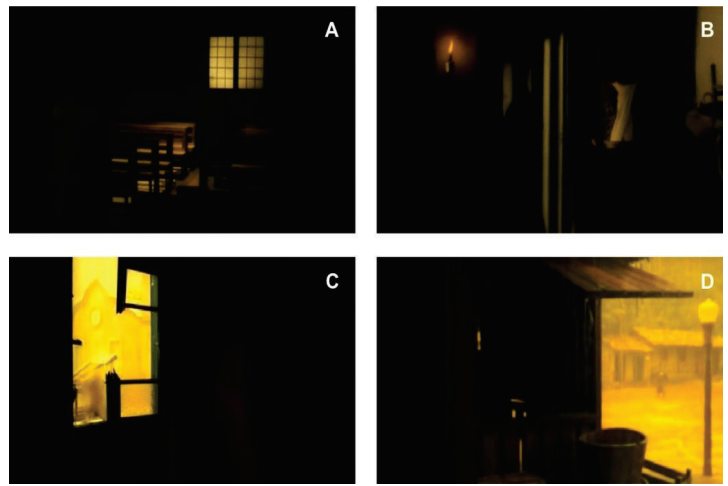

Essa estratégia da luz já traduz, nesse primeiro momento, as significações profundas do romance (ser e parecer) bem como a atmosfera (dúbia) que paira sobre o vilarejo durante todo o desenrolar da história. Além de traduzir sentidos, as imagens também traduzem características objetivas dos ambientes. Seguem, abaixo, algumas das passagens em que o narrador nos fornece características referentes à ambientação (GARCÍA MÁRQUEZ, 2010, grifo dos autores).

En el interior de su lúgubre tienda de armarios desocupados [...] (p. 122).

(...) el olor del excusado y luego el interior lúgubre de la iglesia (...) (p. 111).

[...] en la salita iluminada por la bombilla lúgubre del balcón (p. 150).

[...] yacía frente al ventilador eléctrico en la sala en 
penumbra (p. 140).

El calor se hizo más intenso [...]. Un vapor de tierra húmeda penetró en el cuarto (p. 25).

[...] mientras se encendían las luces en la calles desiertas (p. 165).

Toda a descrição no romance, seja dos ambientes internos ou externos, remete a lugares escuros, úmidos, enlameados, acometidos pela chuva e pelo calor. E o simples efeito dramático criado pela iluminação, neste caso, reage poderosamente a favor da atmosfera sufocante e claustrofóbica que configura o universo imaginário criado por García Márquez. Embora cada meio utilizese de formas peculiares de veicular determinado conteúdo, há uma ligação que se estabelece de maneira irredutível, que independe dessa limitação física e transcende o objeto no afã de alcançar equivalências significantes. Aqui se lida com um problema comum, com a questão da equivalência na diferença, ponto de partida para todo tipo de tradução - seja interlingual, intralingual, ou intersemiótica ${ }^{6}$.

O conceito visual apresentado no filme - enfatizando a luz e a sombra e seus altos contrastes - assemelha-se à estética da escola barroca. Na pintura barroca artistas fizeram da iluminação sua grande ferramenta pictórica. É bom esclarecer que no Renascimento o claro e o escuro foram uns dos elementos que inovaram a maneira de pintar, pois era por meio do chiaroscuro ${ }^{7}$ que as figuras ganhavam rotundidade, entre outros elementos. No barroco, a luz não tem apenas a função de modelagem tridimensional, ela cria atmosfera icônico-simbólica, é intencionalmente utilizada para atingir o emocional e 'prender' o receptor, ao inserí-lo na obra. De acordo com Arnheim (2002, p. 315) "a iluminação tende a guiar a 6 Conforme os estudos de Roman Jakobson (1977, p. 64-65). Basicamente: Interlingual: tradução entre línguas diferentes; Intralingual: tradução no interior de uma mesma língua; Intersemiótica: tradução de uma linguagem para outra dela diversa.

7 Claro-escuro, em italiano. 
atenção seletivamente, de acordo com o significado desejado".

Contudo, em alguns momentos, percebe-se a ocorrência de uma mudança, embora sutil, do conceito visual até então apresentado (altos e baixos contrastes). Nesta imagem (Figura 2) pode-se observar um dos momentos em que ocorre essa mudança. Aqui, Ruy Guerra recorre a uma linguagem antinaturalista por meio de uma iluminação amarela estourada levada a um extremo grau de saturação, contrapondo a ideia do claro-escuro enquanto iluminação natural e possível dentro da proposta estabelecida - um povoado acometido pela instabilidade temporal e sem luz elétrica.

No exemplo, evidencia-se um nítido desequilíbrio, que, por vezes, agride o olhar e destoa do conjunto harmônico até então apresentado. Neste caso, pode-se pensar a imagem como autoreferente, já que chama a atenção do espectador para o artificialismo por meio de uma iluminação maneirista ${ }^{8}$. A natureza e os edifícios parecem gritar exasperados e sufocados na atmosfera proposta que também incita uma reflexão sobre a própria natureza da arte, ou seja, a arte enquanto representação do real.

8 De acordo com o dicionário de termos literários de Carlos Ceia (2010), Maneirismo foi um movimento estético europeu, que marca, a par do Renascimento, um afastamento consciente dos modelos clássicos, e que decorre entre a segunda metade do século XVI e a primeira metade do século XVII. Neste estilo havia uma tendência na pintura ao exagero, ou uma forma de levar a maniera ao extremo da sua representação, abandonando as linhas harmoniosas impostas pelo estilo vigente, criando labirintos, espirais e proporções inesperadas. 
Figura 2 - Externa igreja matriz

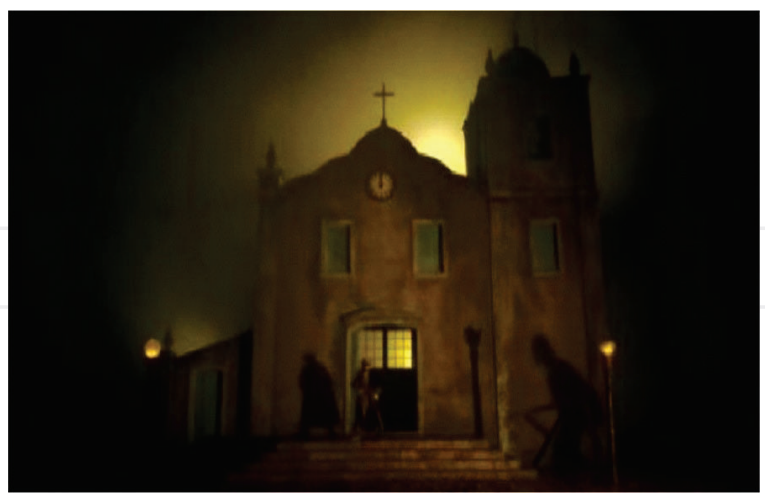

\section{Es todo el pueblo y no es nadie: o observador e o observado}

La mala hora é um romance feito de silêncios, e estes parecem falar mais que muitas palavras. Tudo fica no nível da indefinição e do não-dito. Nada é explicitado. Um exemplo é o próprio conteúdo dos pasquins ou folhetos. Se estes veiculam verdades, não se sabe ao certo. Assim como não sabemos quem os espalha pelo povoado.

Ao mesmo tempo em que os papeluchos funcionam como desmascaramento (pois tocam em assuntos, acontecimentos que causariam escândalos e mudanças se revelados), esse meio de comunicação funciona para apontar que ali quase todos, ou melhor dizendo, os membros da classe dominante vestem máscaras sociais que escondem as monstruosidades por eles cometidas. Esse jogo entre o lado de cá e o de lá, entre olhar e espreitar o alheio presentes na narrativa garcíamarqueziana, viram matéria fundamental à recriação de Ruy Guerra (Figuras3 e 4).

Essas sequências remetem à questão do jogo de observador e observado - reflexo do dito e não dito, ou do agir às claras e às escuras -, presente no romance. A iluminação diferenciada apresenta dois ambientes distintos: o interno e o externo. Nas cenas nota-se, 
pela escassez de luz e pelas faixas retangulares pretas colocadas em cada extremo, que o observador/narrador está no interior de um recinto. E que o ambiente externo (claro) está posicionado ao centro das duas faixas. A luz e o deslocamento de espaço (dentro e fora) indicam que algo está exposto e outro está escondido. O escuro coloca-se em cena para reforçar os sentidos embutidos na intenção daquele que observa. Intenção essa que busca a preservação da sua identidade. Há um desejo de saber da vida alheia sem ser visto ou implicado.

Figura 3 - Câmera flagra Dr Giraldo observando o Alcaide
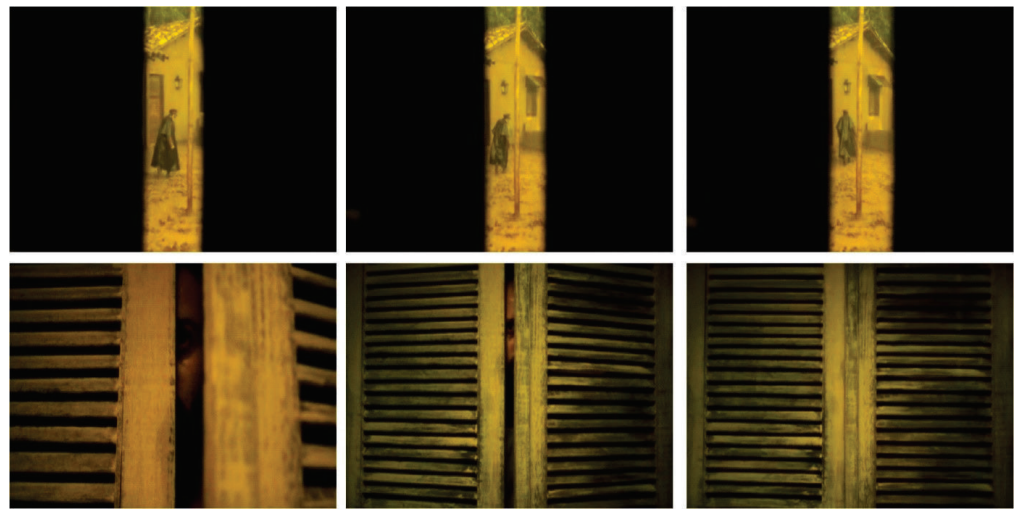

Figura 4 - Câmera aponta o modo de Rosário observar Trinidad
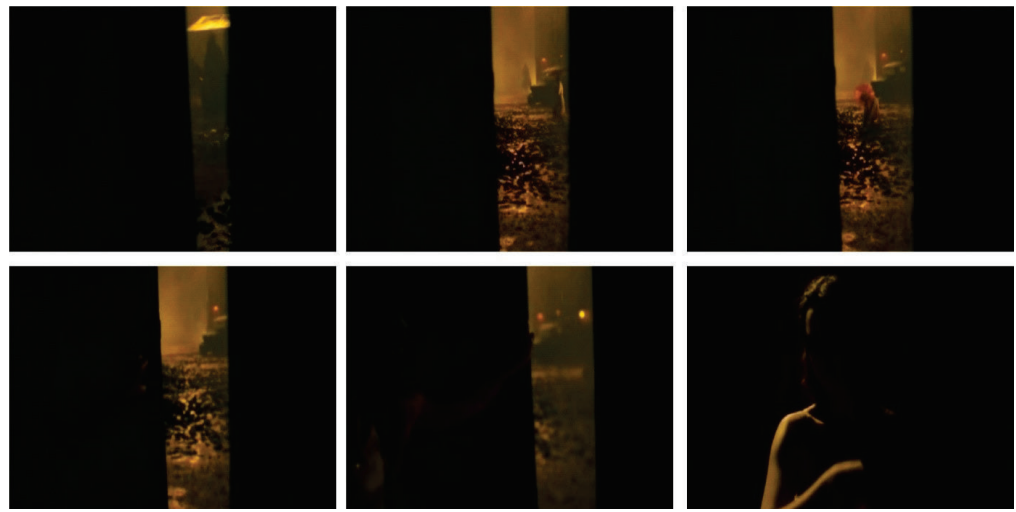
Todo o ambiente de constante vigília presente no romance é traduzido intersemioticamente com força por Ruy Guerra, como se pode notar. No livro, isso se configura em vários momentos. Os personagens sempre estão fazendo referências não assertivas; o Outro é sempre motivo de conversa e especulação no discurso das personagens. Segue um exemplo, a título de ilustração, dessa ideia.

- Anoche hubo serenata - dijo.

- De plomo - confirmó Mina -. Sonaron disparos hasta hace poco.

- [...]. Parece que se volvieron locos buscando hojas clandestinas. Dicen que levantaron el entablado de la peluquería, por casualidad, y encontraron armas. [...]

- Y eso no es nada-dijo Mina-. Anoche, a pesar del toque de queda e a pesar del plomo... (GARCÍA MÁRQUEZ, 2010, p. 206-207, grifo dos autores).

O discurso das personagens produz imprecisão no relato contado. A utilização das formas verbais "dizem", "soaram", "parece que" quita a responsabilidade de quem conta, de afirmação sobre o conteúdo daquele que emite a mensagem, confiando a "eles", aos "outros" a autoria e veracidade de determinado assunto. Interessante perceber o desejo de transmitir a mensagem, mesmo que de maneira reticente. O ponto culminante desse clima - onde todos são vistos como potenciais autores dos panfletos es todo y no es nadie - pode ser bem mostrado a partir da atitude do Alcaide, que, num impulso de desespero (que não deixa de ser ridículo) recruta os próprios civis para que estes passem a madrugada vigiando o povoado, em busca do possível autor das fofocas. Todos esses elementos apontados até aqui também recriam artisticamente as questões implícitas na dualidade dominador/dominado presente no texto-fonte, em que todos são, simultaneamente, observadores e observados, tiranos e vítimas/ testemunhas da história. 


\section{Luz, sombra e danação!}

Outra característica presente na composição visual que não pode ser desprezada diz respeito à sombra projetada. Essa marca remete-nos à fotografia dos dois maiores fotógrafos do Expressionismo Alemão9: Fritz Arno Wagner que fotografou Nosferatu (1922), de Friedrich Murnau, e Karl Freund que fotografou M, o Vampiro de Dusseldorf (1931), de Fritz Lang. O diálogo estabelecido entre estes filmes e $O$ veneno da madrugada se dá, principalmente, a partir do agigantamento das sombras e a projeção destas na parede. Segue abaixo uma das sequências em que Ruy Guerra lança mão do recurso da sombra projetada (Figura $5)$.

A partir da análise desse conjunto de frames, observa-se que a iluminação presente em alguns dos quadros em que ocorre tal projeção apresenta uma forte relação com a ideia do assustador presente no agigantamento das imagens, além de trazer à tona o tema das ações realizadas na calada da noite: imorais, indecorosas. As projeções se colocam em cena como elementos narrativos e assim reforçam a dubiedade existente nos seres da fábula: em suas vidas pessoais e em suas relações sociais, políticas e econômicas, que têm interferência direta na vida daquela comunidade. As sombras ganham o tom enigmático e suspeito de ocultamento de atos.

9 O termo 'expressionismo' foi forjado pelo crítico e historiador de arte W. Worringer (1911), para qualificar um conjunto de obras pictóricas, e assim opor-se ao impressionismo. A palavra foi em seguida aplicada com sentidos bastantes variáveis à poesia, ao teatro e ao cinema. A corrente expressionista agrupa poucos filmes alemães mudos. Dentre as características do expressionismo cinematográfico temos o tratamento da imagem como gravura (forte contraste entre o preto e o branco); o jogo enviesado dos atores e o tema da revolta contra a autoridade (AUMONT; MARIE, 2003, grifo dos autores). 
Figura 5 - Personagem do Alcaide - a sombra projetada: deformação de caráter e imposição do medo
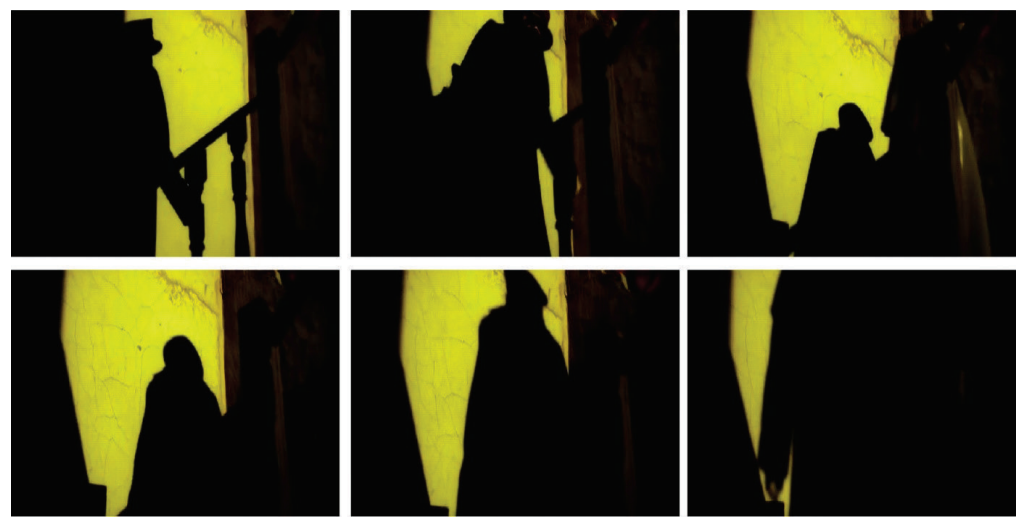

\section{Luz: mostrar e esconder}

No filme, a iluminação opera como uma luz cênica semelhante àquela utilizada no teatro, quando então, no palco, esta direciona a nossa atenção sobre um determinado objeto ou personagem.

Nos frames abaixo (Figura 6), o movimento visual ocorre por meio dos contrastes de claro e escuro. É por meio destes que o olho é conduzido de maneira contemplativa pela imagem. Porém, ao mesmo tempo em que a pulsação visual criada pelos closes, ou aproximações da câmera e detalhamento das expressões faciais dos personagens movimenta o apreciar, em determinadas regiões contrastantes, o olhar é obrigado a repousar por alguns instantes sobre esse efeito. Assim, o halo de luz que banha as faces destacadas em vários momentos do filme, resultando num instigante jogo de claro-escuro também, passa a reforçar a dor e a tragicidade que circundam a existência desses seres. 
Figura 6 - A iluminação na face das personagens
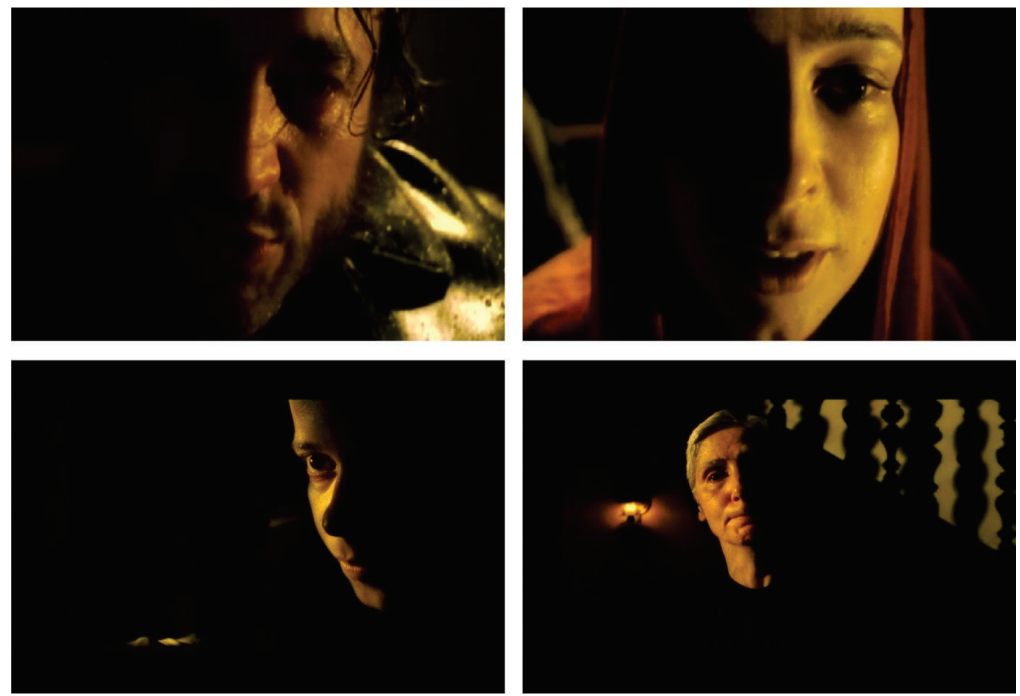

A partir dessas análises, espera-se que tenha ficado evidenciado parte do laborioso exercício de tradução intersemiótica operado por meio da iluminação em $O$ veneno da madrugada, trabalho de Guerra e Carvalho que buscou a cada detalhe evocar e traduzir para o cinema dos anos 2000 as ressonâncias políticas e psicológicas contidas na moral da fábula La mala hora.

\section{Referências}

ARNHEIM, Rudolf. Arte e percepção visual: uma psicologia da visão criadora. São Paulo: Pioneira, 2002.

AUMONT, Jacques; MARIE, Michel. Dicionário teórico e crítico de cinema. Campinas: Papirus, 2003.

CAMPOS, Haroldo de. Metalinguagem e outras metas. 4. ed. São 
122 A recriação poética da palavra na fotografia do filme “0 veneno da madrugada”, de Ruy Guerra

Paulo: Perspectiva, 2004.

CEIA, Carlos. Maneirismo. In: CEIA, Carlos (Coord.). E-Dicionario de termos literarios. Disponível em $<$ http://edtl. fcsh.unl.pt/business-directory/6530/maneirismo/>. Acesso em: 10 mar. 2016.

GARCÍA MÁRQUEZ, Gabriel. La mala hora. 5. ed. Buenos Aires: Debolsillo, 2010.

GREIMAS, Algirdas Julien. Semântica estrutural: pesquisa e método. 2. ed. São Paulo: Cultrix, 1966.

JAKOBSON, Roman. Linguística e comunicação. 9. ed. Tradução: Izidoro Blikstein e José Paulo Paes. São Paulo: Cultrix, 1977.

LEAL, João Vitor. Walter Carvalho: a fotografia além da fotogenia. Cinémas d`Amérique Latine, Touluse, n.20, p. 43-50, 2012.

LEONE, Eduardo; MOURÃO, Maria Dora. Cinema e montagem. 2. ed. São Paulo: Ática, 1993.

RICHARDS, Ivor Armstrong. Princípios de crítica literária. 2. ed. Tradução: Rosaura Eichenberg, Flávio Oliveira e Paulo Roberto do Carmo. Porto Alegre: Globo, 1971.

VENENO DA MADRUGADA (O). Direção: Ruy Guerra. Brasil. Distribuição: Universal Pictures, 2004. 